\title{
REVIEW
}

\section{Next-generation sequencing technologies: Tool to study avian virus diversity}

\author{
S. S. KAPGATE ${ }^{1}$, S. B. BARBUDDHE2 ${ }^{*}$, K. KUMANAN ${ }^{3}$
}

\begin{abstract}
${ }^{1}$ Department of Animal Biotechnology, Madras Veterinary College, Tamil Nadu Veterinary and Animal Sciences University, Chennai, India; ${ }^{2}$ National Institute of Biotic Stress Management, Office of DSW, 1st Floor, IGKVV Campus, Krishak Nagar, Raipur-492012 India; ${ }^{3}$ Directorate of Research, Tamil Nadu Veterinary and Animal Sciences University, Madhavaram, Chennai-600051, India
\end{abstract}

\begin{abstract}
Summary. - Increased globalisation, climatic changes and wildlife-livestock interface led to emergence of novel viral pathogens or zoonoses that have become serious concern to avian, animal and human health. High biodiversity and bird migration facilitate spread of the pathogen and provide reservoirs for emerging infectious diseases. Current classical diagnostic methods designed to be virus-specific or aim to be limited to group of viral agents, hinder identifying of novel viruses or viral variants. Recently developed approaches of next-generation sequencing (NGS) provide culture-independent methods that are useful for understanding viral diversity and discovery of novel virus, thereby enabling a better diagnosis and disease control. This review discusses the different possible steps of a NGS study utilizing sequence-independent amplification, high-throughput sequencing and bioinformatics approaches to identify novel avian viruses and their diversity. NGS lead to the identification of a wide range of new viruses such as picobirnavirus, picornavirus, orthoreovirus and avian gamma coronavirus associated with fulminating disease in guinea fowl and is also used in describing viral diversity among avian species. The review also briefly discusses areas of viral-host interaction and disease associated causalities with newly identified avian viruses.
\end{abstract}

Keywords: next-generation sequencing; viral metagenomics; viral transcriptomics; virus diversity; DNA; RNA; genome; gene

\section{Contents:}

1. Introduction

2. Classical methods for study of virus diversity

3. NGS technologies

3.1 Genome characterization and virus diversity

*Corresponding author. E-mail: barbuddhesb@gmail.com; phone: +91-7712444697.

Abbreviations: AIV = avian influenza virus; AGV 2 = avian gyrovirus 2; aHEV = avian hepatitis E virus; APMV-1 = avian paramyxovirus 1; ILTV = infectious laryngotracheitis virus; ITV = Israel turkey meningoencephalitis virus; LPDV = lymphoproliferative disease virus; $\mathrm{MDV}=$ Marek's disease virus; $\mathrm{NGS}$ = next-generation sequencing; PPMV-1 = pigeon paramyxovirus 1; USUV = Usutu virus; $\mathrm{WNV}=$ West Nile virus
3.2 Virus discovery and viral metagenomics

3.3 Transcriptomics and virus-host interaction

4. Evidence of causal virus-disease relationship

5. Conclusions and perspectives

\section{Introduction}

Globalisation, climate change, wildlife-livestock interface, changes in agricultural practices (e.g. intensive farming), growth in live animal market are some of the drivers responsible for the emergence of novel pathogens and zoonoses (Jones et al., 2013). Among the animal species, wild birds are well-known reservoirs of emerging infectious diseases such as avian influenza (AI) and West Nile (WN) in humans 
(Mackenzie and Jeggo, 2013; Wang et al., 2014a). Besides the zoonotic agents, the emergence of new serotypes and genotypic variants of known avian viruses are recognized as potential agents responsible for new infectious diseases (Jackwood and Handel, 2012). High biodiversity of the wild bird population can increase the risk of pathogen spill over to domesticated poultry. Additionally, bird migration also provides a facility to spread the pathogen or dispersing infected arthropod vectors at multiple geographic scales (Mackenzie and Jeggo, 2013). Understanding of virus diversity may be used for forecasting future transmission risks or eventual outbreaks of viral diseases. However, identification or monitoring of the circulation of unrecognized viruses is one of most important requirements for the response to disease outbreaks.

Many classical methods such as electron microscopy, tissue culture or serology were used for virus detection and discovery. Electron microscopy provides only morphologic clues; however many viruses are not culturable. Serological tests depend on the availability of quality antiserum, hindering identification and discovery of viral pathogens; however this can be achieved by molecular methods (Bexfield and Kellam, 2011). During recent decades, introduction of molecular methods has allowed the direct detection and characterisation of the genome sequences of various infectious agents. However, most of the conventional molecular assays are designed to be virus specific or aimed at a limited group of infectious agents. This makes them unsuitable for the detection of unexpected and/or completely new viruses, as well as novel viral variants.

The Sanger sequencing has been standard diagnostic tool for detecting and identifying various pathogens. Nevertheless use of Sanger sequencing provides less sequence information, high cost, and it is used to identify high titre pathogens. With development of novel modern molecular biology technologies, sequence-independent amplification and next-generation sequencing (NGS) offer higher sequencing capacity, speed and lower cost per nucleotide relatively to Sanger sequencing technique. Moreover, NGS allows unbiased detection of a very wide range of infectious agents in a culture-independent manner (Lipkin, 2013). In the field of virology, NGS technologies have been widely used for investigation of genome diversity, virus discovery, metagenomics, discovery of non-coding viral RNAs and gene expression profiling (Radford et al., 2012). This review discusses the different possible steps of avian virus diversity and discovery using next-generation sequencing technologies.

\section{Classical methods for study of virus diversity}

Cell culture has been the gold standard method for virus discovery and downstream analysis of viruses with other diagnostic methods, including electron microscopy, serology and PCR. These other methods accompanied by use of virus culturing have been reported in identification of chicken proventricular necrosis virus (CPNV) and adenoviral gizzard erosion in broiler chickens (Guy et al., 2011; Schade et al., 2013). Currently, a variety of singleplex serological and molecular assays are used for avian viral disease diagnosis. Multiplex assays can be more useful in differential diagnosis. Recently, multiplex fluorescent microsphere immunoassay has been developed for simultaneous detection of avian influenza virus (AIV) antibodies against (H1-H16) subtypes and avian paramyxovirus serotype 1 (APMV-1) (Pinette et al., 2014). A wide range of genetic methods have been established for multiplex detection of various poultry viruses causing enteric and respiratory syndromes (Nguyen et al., 2013). Even higher levels of multiplexing can be obtained with DNA microarrays and panviral microarrays that can comprise millions of individual probes to identify or discover divergent avian viruses (Kistler et al., 2008; Maughan et al., 2014).

Sequencing of gene or genome is playing an important role in virus characterisation, epidemiological studies and has also allowed the discovery of new viruses. Novel RNA sequences of an avian calicivirus were revealed from intestinal contents of poultry (Wolf et al., 2012). Novel avian picornavirus species (turdivirus 1 and 2) from wild birds (Woo et al., 2010), pigeon picornaviruses (Kofstad and Jonassen, 2011), quail picornavirus (Pankovics et al., 2012) and two novel picornaviruses (Gallivirus) were discovered (Farkas et al., 2012). Aalivirus, a novel duck origin picornavirus has been reported in China (Wang et al., 2014b). The picobirnaviruses are recently described group of viruses in several mammal species that contain dsRNA, bi-segmented genomes and are classified into two distinct genogroups (I or II). Avian picobirnaviruses (AvPBV) genogroup I in Brazilian broiler chickens and distinct group of turkey origin picobirnavirus have been identified (Ribeiro Silva et al., 2014; Day and Zsak, 2014). A novel avian hepatitis E virus (aHEV) genotype IV has been identified in Hungary and Taiwan (Banyai et al., 2012; Hsu and Tsai, 2014). CPNV associated with transmissible viral proventriculitis in broiler chicken was identified as a novel avian birnavirus, representing a distinct genetic cluster within the Birnaviridae family (Guy et al., 2011). Novel psittacid herpesvirus 3 and phasianid herpesvirus have been identified with respiratory disease in Bourke's parrots and pheasants with fatal infection, respectively (Shivaprasad and Phalen 2012; Seimon et al., 2012). An existence of a distinct avian papillomavirus group has been reported in various birds (Johne et al., 2009). A novel wood pigeon and feral pigeon astrovirus were identified in Norway (Kofstad and Jonassen, 2011). Rubbenstroth et al. (2014) discovered a new avian bornavirus genotype in estrildid finches (Estrildidae) in Germany. Emerging novel orthomyxovirus, named as 
Wellfleet Bay virus has been reported in eider ducks (Pello and Olsen, 2013). A novel siadenovirus has been identified from polar seabird (Park et al., 2012). During the surveillance for arboviral encephalitis, Travassos de Rosa et al. (2002) identified rhabdoviruses from wild birds.

A wide variety of genetic and antigenic variants of novel avian coronaviruses have been reported in poultry (Jackwood and Handel, 2012). Interspecies transmission of avian coronaviruses and emergence of a novel gamma and delta coronavirus were identified in wild aquatic birds (Woo et al., 2009). A wide genetic diversity of novel avian astroviruses detected in different species of wild birds which showed different groups of astroviruses had different host ranges (Chu et al., 2012). Role of recombination has been documented to be a contributing factor in emergence of turkey coronavirus (TCoV): the $S$ gene of infectious bronchitis virus (IBV) recombined with an unknown virus (likely of avian origin), which resulted in a host change (chicken to turkey) and a tropism switch (respiratory to enteric) (Jackwood et al., 2010). Sarker et al. (2014) reported quasispecies variants and recombination events in an outbreak of emerging beak and feather disease virus (BFDV) that caused psittacine beak and feather disease. Chicken anemia virus (CAV) was the only known representative of the Gyrovirus genus, novel avian gyrovirus 2 (AGV2) and genetic variants of AGV2 were reported in chickens (Rijsewijk et al., 2011; Dos Santos et al., 2012). Avian orthoreoviruses have been associated with a variety of diseases in chickens. Dandar et al. (2013) characterized divergent avian reovirus strain from a broiler chicken with central nervous system disease. For the first time, Beserra et al. (2014) reported the occurrence of rotavirus group F in broiler from Brazil. Gyuranecz et al. (2013) established worldwide phylogenetic relationship of avian poxviruses and provided novel insights into the complex relationship between avian poxviruses and their hosts.

Evidence for intercontinental spread of APMV-1 class II genotype I was provided in migratory wild birds (Ramey et al., 2013). A distinct class II genotype VI consisting of a globally diverse range of pigeon paramyxovirus 1 (PPMV-1) strains has been identified among feral and domestic pigeons (Snoeck et al., 2013). Wild waterfowl is the major reservoir of all influenza A virus subtypes. Highly pathogenic AIV (HPAIV) has been reported to emerge after transmission of low-pathogenic AIV (LPAIV) from wild reservoir to gallinaceous birds. Wu et al. (2013) reported emergence of $\mathrm{H} 7 \mathrm{~N} 9$ viruses by sequential reassortments involving distinct H9N2 donor viruses from wild birds and domestic birds. Parvin et al. (2014) identified H9N2, a LPAIVs internal gene reassortment with H5N1, a HPAIV in commercial and backyard poultry. Emergence of H5N8 has been identified in domestic poultry and wild birds with high mortality in domestic poultry (Lee et al., 2014). Recently, emerging H7, H6 and H10 AIV subtype viruses have been detected frequently in the live poultry markets causing serious concerns to the poultry industry and human health (Wang et al., 2014c; To et al., 2014). Lymphoproliferative disease virus (LPDV), an oncogenic avian retrovirus has been reported in domestic turkeys in Europe and Israel for decades. Allison et al. (2014) described emerging LPDV in wild birds and genetic diversity and evolution of LPDV in the United States.

As natural reservoirs or amplifier hosts, birds play an important role in the maintenance and transmission of flaviviruses. Some flaviviruses cause disease in domestic poultry or captive game birds. The emergence of widespread flavivirus named, duck Tembusu Virus (DTMUV), with distinct genotypes has been demonstrated in domestic ducks in China (Yu et al., 2013). Outbreaks of West Nile virus (WNV) have been reported in domestic duck flocks (Wojnarowicz et al., 2007). Emergence and establishment of Usutu virus (USUV) infection was reported in wild and captive avian species in Europe (Steinmetz et al., 2011). Two different species of Flavivirus genus, Israel turkey meningoencephalitis virus (ITV) in turkeys and Bagaza virus (BAGV) in wild partridges and pheasants were identified (Llorente et al., 2013). Based on serological and phylogenetic comparison, Fernández-Pinero et al. (2014) reported ITV and Bagaza virus were the same virus species and proposed unified name avian meningoencephalomyelitis virus for both viruses.

\section{NGS technologies}

Several commercially available high-throughput sequencing platforms exist that vary by way of their sequencing principle, sequencing speed, expense, and read length. NGS essentially entails the following steps: sample preparation, sequence-independent amplification, high-throughput sequencing, and bioinformatics analysis as outlined in Fig. 1.

Due to low abundance of viral sequences relative to total host nucleic acids, viral enrichment and concentration procedure requires to remove non-viral nucleic acid. To enrich viral nucleic acid, several measures have been taken such as homogenization, filtration, chloroform treatment, ultracentrifugation, nuclease treatment or combinations of these methods prior to viral nucleic acid extraction (Hall et al., 2014).

The amount of total nucleic acids isolated from viral particles is often too low for sequencing and may require amplifying of viral nucleic acid. The amplification has been aided by the development of sequence independent methodologies which simultaneously amplify several highly divergent viral genomes (Rosseel et al., 2013). Sequence-independent single-primer amplification (SISPA), random PCR (rPCR), multiple displacement amplification (MDA) or virus discovery cDNA-amplified fragment length polymorphism (VIDISCA) are commonly used sequence-independent 


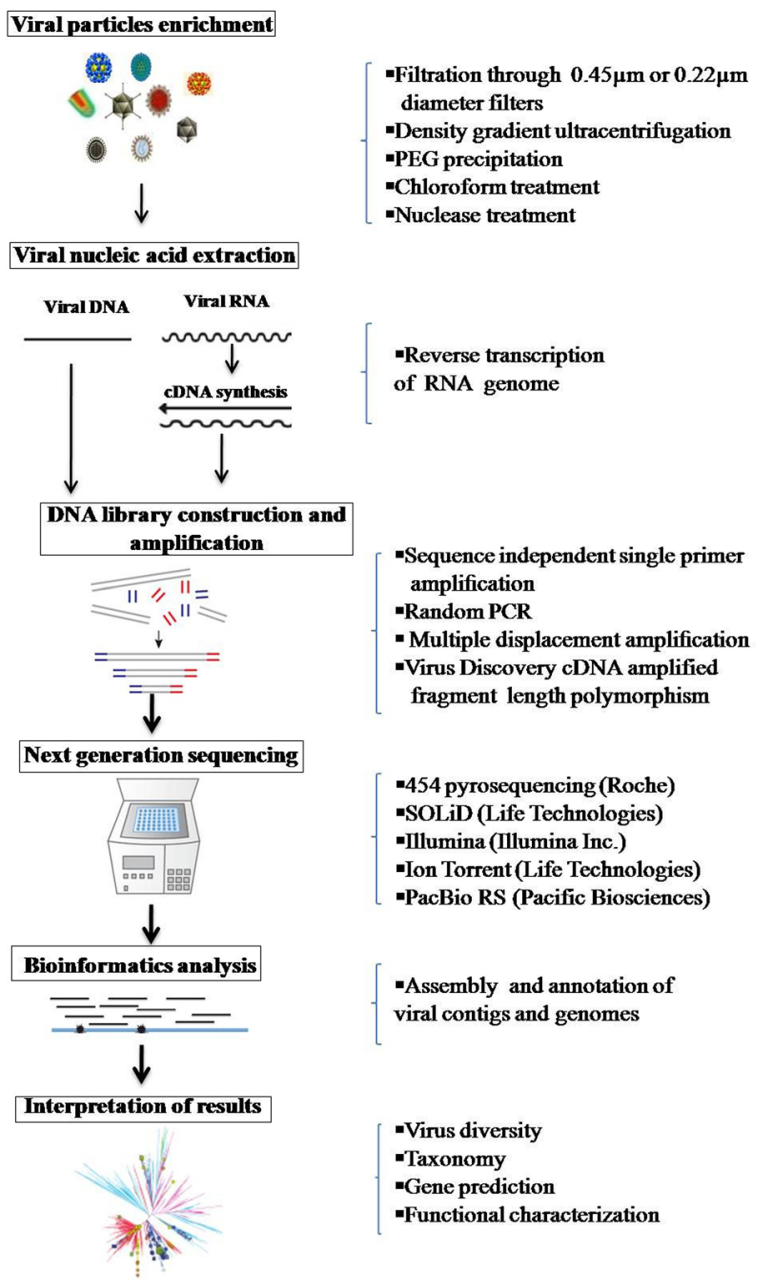

Fig. 1

Workflow for virus detection using next-generation sequencing

amplification methods (Johne et al., 2009; de Vries et al., 2011; Sujayanont et al., 2014).

NGS platforms require the viral genomic sequences in the samples to be converted into sequencing libraries and later their amplification. Sequencing libraries are constructed by fragmenting the DNA (or cDNA) sample and ligating adapter sequences onto the ends of the DNA fragments and clonal amplification for sequencing. NGS technologies are based either on sequencing by synthesis or sequencing by ligation reaction controlled by polymerase or ligase. 454 pyrosequencing (Roche) is based on emulsion PCR (emPCR), in combination with a sequencing-by-synthesis approach. SOLiD (Applied Biosystems) also uses emPCR for clonal DNA amplification on beads to allow sequencing by ligation. Illumina (Illumina Inc.) is based on bridge-PCR on the surface of glass flow cell and uses sequencing-by-synthesis approach. Ion Torrent (Life Technologies) is sequencingby-synthesis method that also uses emPCR. Ion Torrent detection relies on ion-sensitive, field-effect transistorbased sensors to measure hydrogen ions released during polymerase-mediated incorporation. PacBio RS (Pacific Biosciences) is able to sequence single DNA molecule in real time without the need for clonal amplification. Currently, Nanopore sequencers (Oxford Nanopore Technologies) are being developed, which are based on the concept that single DNA molecule can be identified when passing through engineered nanopore protein immobilised on a solid surface. A detailed comparison and performance of various NGS instruments have been reviewed elsewhere (Mardis, 2013; $\mathrm{Ku}$ and Rouks, 2013).

The applications of NGS technologies in avian virology with examples are listed in Table 1.

\subsection{Genome characterization and virus diversity}

Molecular epidemiology using nucleotide or full genome sequence data is widely used to monitor transboundary movements of avian viruses which clarify our understanding of the genetic diversity and viral evolution. Moreover, genomic sequences of viral strains can be used to identify the molecular determinants that underpin important phenotypic traits such as virulence and pathogenicity and prediction of novel genes and viral features that are important for viral replication or pathogenesis. NSG techniques have been used to sequence and conduct comparative full genome analysis of district genotype of infectious laryngotracheitis virus (ILTV) (Spatz et al., 2012). Complete genomes of fowl adenovirus A to E species (Marek et al., 2013) and the nonchicken aviadenovirus species has been reported (Kajan et al., 2010), which provided phylogeny and evolution of the genus Aviadenovirus. Recently, Marek et al. (2014) revealed the existence of two unknown lineages and common evolutionary origin of turkey adenovirus 5 (TAdV-5) and fowl adenovirus 1 (FAdV-1). Bodewes et al. (2013) identified novel gull adenovirus and demonstrated that birds of the Laridae family are infected by family-specific adenoviruses.

Many RNA viruses exhibit extreme evolutionary dynamics and genetic diversity due to the high mutation rates and short generation times (Beerenwinkel et al., 2012). APMVs are composed of the antigenically and genetically distinct avian paramyxovirus serotypes APMV 1 to 9 and two more APMV-10 and APMV-11 serotypes have been suggested (Miller et al., 2010; Briand et al., 2012). Based on antigenic and genetic characterization, Terregino et al. (2013) proposed new APMV-12 group. Forrester et al. (2013) revealed ancestral lineage of APMV 1 class II genotype XII isolated from Indonesia and provided an insight into historic Newcastle disease virus (NDV) evolution. Van Borm et al. (2013) identified genome sequence variability in PPMV-1 isolates from Belgium. Three APMVs, two different APMV-4 and one APMV-6 were identified (Rosseel 
Table 1. Application of next generation sequencing technologies in avian virology

\begin{tabular}{|c|c|c|c|}
\hline NGS methods & Application & Examples & References \\
\hline \multirow{15}{*}{$\begin{array}{c}\text { Genome } \\
\text { sequencing }\end{array}$} & \multirow{3}{*}{$\begin{array}{l}\text { Genomic characterization } \\
\text { and gene discovery }\end{array}$} & $\begin{array}{l}\text { Revealed the unique genome feature like internal ribosomal entry site and aphthovi- } \\
\text { rus 2A-like sequence with 'ribosome-skipping' sites in avian picornaviruses }\end{array}$ & $\begin{array}{l}\text { Boros et al. } \\
(2014)\end{array}$ \\
\hline & & $\begin{array}{l}\text { Identified a novel small-RNA population encoded from exogenous virus-specific } \\
\text { region E (XSR) element of avian leukosis virus subgroup J (ALV-J) }\end{array}$ & $\begin{array}{l}\text { Yao et al. } \\
(2014)\end{array}$ \\
\hline & & $\begin{array}{l}\text { Provided evidence for a role of Nsp14-Exonuclease (nsp14-ExoN) in RNA proof- } \\
\text { reading during coronavirus replication }\end{array}$ & $\begin{array}{l}\text { Eckerle et al. } \\
(2010)\end{array}$ \\
\hline & \multirow[b]{2}{*}{$\begin{array}{l}\text { Molecular determinants } \\
\text { associated with virulence }\end{array}$} & $\begin{array}{l}\text { Identification of emergence of virulence-associated E627K substitution in polymer- } \\
\text { ase basic protein of H7N7 as adaptation marker }\end{array}$ & $\begin{array}{l}\text { Jonges et al. } \\
(2014)\end{array}$ \\
\hline & & $\begin{array}{l}\text { Identification of US10 gene and UL41 gene associated with reversion to virulence of } \\
\text { low and high passages of tissue culture origin and chicken embryo origin infectious } \\
\text { laryngotracheitis vaccine strains respectively }\end{array}$ & García et al. \\
\hline & \multirow{2}{*}{$\begin{array}{l}\text { Characterization of viral } \\
\text { quasispecies }\end{array}$} & $\begin{array}{l}\text { Presented evidence of quasispecies and mixed infections among avian influenza } \\
\text { A viruses }\end{array}$ & $\begin{array}{l}\text { Ramakrishna } \\
\text { et al. (2009) }\end{array}$ \\
\hline & & $\begin{array}{l}\text { Characterized quasispecies composition and genomic diversity of pigeon paramyxo- } \\
\text { virus type-1 }\end{array}$ & $\begin{array}{l}\text { Van Borm et } \\
\text { al. ( 2013) }\end{array}$ \\
\hline & \multirow{3}{*}{ Novel pathogen discovery } & $\begin{array}{l}\text { Discovery of a novel orthomyxovirus, designated Cygnet river virus, within genus } \\
\text { quarjavirus in Muscovy ducks }\end{array}$ & $\begin{array}{l}\text { Kessell et al. } \\
(2012)\end{array}$ \\
\hline & & $\begin{array}{l}\text { Discovery of Farmington virus as a new species within the family Rhabdoviridae } \\
\text { isolated from a wild bird }\end{array}$ & $\begin{array}{l}\text { Palacios et } \\
\text { al. }(2013)\end{array}$ \\
\hline & & $\begin{array}{l}\text { Discovery of Tvarminne avian virus as a candidate new species within the genus } \\
\text { orthoreovirus in a crow }\end{array}$ & $\begin{array}{l}\text { Dandar et al. } \\
(2014)\end{array}$ \\
\hline & \multirow{2}{*}{ Viral metagenomics } & $\begin{array}{l}\text { Metagenomic identification of several viral families, such as Picornaviridae, } \\
\text { Caliciviridae and Picobirnaviridae from turkey gut }\end{array}$ & $\begin{array}{l}\text { Day et al. } \\
(2010)\end{array}$ \\
\hline & & Characterization of enteric virome in droppings from wild pigeons & $\begin{array}{l}\text { Phan et al. } \\
(2013)\end{array}$ \\
\hline & $\begin{array}{l}\text { Virus associate with disease } \\
\text { of unknown etiology }\end{array}$ & $\begin{array}{l}\text { Identification of a novel avian gammacoronavirus associated with Fulminating dis- } \\
\text { ease ('X disease') of guinea fowl }\end{array}$ & $\begin{array}{l}\text { Liais et al. } \\
(2014)\end{array}$ \\
\hline & Immune escape & $\begin{array}{l}\text { Investigation of the emergence of escape mutants during serial in-vitro passaging of } \\
\text { H5N1 AIV under immune pressure }\end{array}$ & $\begin{array}{l}\text { Hooper et al. } \\
(2012)\end{array}$ \\
\hline & $\begin{array}{l}\text { Quality control of live } \\
\text { attenuated viral vaccines }\end{array}$ & $\begin{array}{l}\text { Detection of nucleic acids from endogenous avian leukosis virus in live attenuated } \\
\text { viral vaccines derived from chicken embryo fibroblasts }\end{array}$ & $\begin{array}{l}\text { Victoria et } \\
\text { al. }(2010)\end{array}$ \\
\hline \multirow{4}{*}{$\begin{array}{c}\text { RNA } \\
\text { sequencing }\end{array}$} & \multirow{2}{*}{$\begin{array}{l}\text { Discovery of viral non } \\
\text { coding RNA }\end{array}$} & $\begin{array}{l}\text { Identification of role of viral encoded microRNAs in tumour transformation and } \\
\text { latency in Marek's disease virus }\end{array}$ & $\begin{array}{l}\text { Hicks and } \\
\text { Liu (2013) }\end{array}$ \\
\hline & & $\begin{array}{l}\text { Identification of novel miRNAs encoded by duck enteritis in regards to their ge- } \\
\text { nomic positions }\end{array}$ & $\begin{array}{l}\text { Yao et al. } \\
(2012)\end{array}$ \\
\hline & \multirow{2}{*}{ Host-pathogen interaction } & $\begin{array}{l}\text { Discovery of novel genes and signalling pathways associated with disease resistance } \\
\text { to avian influenza virus infection in chickens }\end{array}$ & $\begin{array}{l}\text { Wang et al. } \\
(2014 \mathrm{~d})\end{array}$ \\
\hline & & $\begin{array}{l}\text { Identification of MYC, TERT, and ZIC1 genes as common targets for viral integra- } \\
\text { tion and transcriptional deregulation in ALV-J induced myeloid leukosis }\end{array}$ & $\begin{array}{l}\text { Li et al. } \\
(2014)\end{array}$ \\
\hline $\begin{array}{l}\text { Chromatin im- } \\
\text { munoprecipita- } \\
\text { tion sequencing }\end{array}$ & DNA-protein binding & $\begin{array}{l}\text { Identification of binding sites occupied by Marek's disease virus oncoprotein, (Meq) } \\
\text { and/or c-Jun within the chicken genome }\end{array}$ & $\begin{array}{l}\text { Subrama- } \\
\text { niam et al. } \\
(2013)\end{array}$ \\
\hline
\end{tabular}

et al., 2011) and their genetic diversity within the serotypes was demonstrated. NGS approaches have been approved for use in routine diagnostics to monitor the genomic diversity of AIV, early emergences and transmission of these viruses from waterfowl to domestic poultry (Croville et al., 2012). Based on ultra-deep sequencing approaches, evidence of emerging HPAIV from a LPAIV progenitor (H7N1) has been provided (Monne et al., 2014). USUV and WNV are members of Flavivirus genus belonging to the Japanese encephalitis antigenic complex and are phylogenetically closely related. First epizootic emergence of USUV in wild and captive birds in Germany and WNV genetic variability has been reported from birds in USA (Becker et al., 2012; Grinev et al., 2013). Divergent avian origin picornavirus genera such as Avisivirus, Megriviruses and Mesiviruses have been identified from turkeys and chickens (Ng et al, 2013; Boros et al., 2014). Two novel picornaviruses (mesivirus 1 and 2) were identified from wild pigeons (Pham et al., 2013). 
Most recently, Bullman et al. (2014) identified picornavirus (Sicinivirus) from chickens which form a monophyletic group with Passerivirus (formerly turdivirus 1) and proposed novel genus within Picornaviridae family.

The highly variable mixture of closely related genomes within a given host is referred as quasispecies. NGS technologies which sequence viruses with ultra-deep coverage ('ultra-deep sequencing') are able to track genomic changes over time and are high enough to capture rare variants. NGS approaches have significantly improved our understanding of the intra-host viral population dynamics. The feasibility of using ultra-deep sequencing to reveal the genomic diversity of PPMV-1 and AIV quasispecies has been demonstrated (Ramakrishna et al., 2009; Van Borm et al., 2013).

Using ultra-deep sequencing, Jonges et al. (2014) investigated the viral quasispecies dynamics associated with AIV subtype H7N7 infection and identified emergence of virulence-associated E627K substitution in polymerase basic protein of H7N7 as adaptation marker. To detect the evolution of HPAI virus from LPAI virus within the infected host, Iqbal et al. (2014) reported ultra deep sequencing of hemagglutinin (HA) gene polybasic cleavage site and failed to detect any evidence of HPAI virus signatures.

New evidence obtained from the analysis of whole genome sequences of ILTV vaccine and field strains indicated that recombination between attenuated vaccines belonging to different genotypic lineages in the field resulted in the emergence of novel virulent strains of ILTV (Lee et al., 2013). Evidence of interspecies transmission and reassortment among avian group A rotaviruses has been reported (Schumann et al., 2009). NGS has been employed to characterise an avian group A rotavirus genome containing a novel viral protein (VP) 4 gene which is closely related to mammalian rotaviruses representing an avian/mammalian rotavirus reassortment (Trojnar et al., 2013).

\subsection{Virus discovery and viral metagenomics}

The introduction of culture-independent NGS technologies, termed as viral metagenomics (community genomics), made powerful diagnostic technology to investigate the complete viral genetic populations of a sample. Viral metagenomics is nowadays routinely used for viral detection, novel virus discovery, and divergent virus genome recovery. This approach has been reported in detection of AGV2, avirulent NDV co-infection in chickens with neurological symptoms and high mortality, avipolyomavirus and avipoxvirus co-infection in periocular skin lesion of gery butcherbird (Abolnik and Wandrag, 2014; Bennett and Gillett, 2014). Based on metagenomics data, Belak et al. (2013) reported interstitial nephritis associated with a variant of NDV-V4 vaccine strain. To explore the role of live poultry markets in the origin of the novel human H7N9 virus, Yu et al. (2014) provided direct evidence of coexistence of influenza H7N9 and H9N2 in poultry linked to human H7N9 infection. Reuter et al. (2014) identified novel group of unclassified single-stranded circular DNA viruses called stool-associated circular virus in a faecal sample from a domestic turkey. Tvarminne avian virus (TVAV), avian origin reovirus was identified in a crow showing neurological disorders. Dandar et al. (2014) reported TVAV as a candidate new species within the genus Orthoreovirus. A novel duck specific avian coronavirus genetically closer to some coronaviruses circulating in wild water fowl has been identified (Chen et al., 2013). A novel delta coronavirus and astrovirus were identified in shorebird samples from the Delaware Bay, an important feeding ground for thousands of migratory birds (Honkavuori et al., 2014). Durham and Farmington viruses as new species from wild birds (Allison et al 2011; Palacios et al., 2013) and novel Sunguru virus within Rhahdoviridae family have been discovered from domestic chickens in Uganda (Ledermann et al., 2014). Khurdun virus a new representative of the Orthobunyavirus has been identified from coot (Alkovskhovskii et al., 2013).

Metagenomics have the capacity to detect viruses either as single agents or as syndromes to identify the etiologic agents. Honkavuori et al. (2008) discovered two strains of a novel Borna viruses in psittacine birds with proventriculus dilatation syndrome (PDS) characterised by gastrointestinal dysfunction and neurological signs. To identify a candidate of etiologic agent for turkey viral hepatitis (TVH), Honkavuori et al. (2011) reported picornavirus in liver samples from diseased turkey poults. Fulminating disease (X disease) of guinea fowl is acute enteritis characterised by intense prostration and a very high mortality. Although its viral origin was previously suspected, virus remained unknown. Liais et al. (2014) identified a novel avian gamma coronavirus associated with this disease which was distantly related to TCoVs. To decipher the RNA virus community from turkey flocks experiencing enteric disease, Day et al. (2010) analyzed turkey gut RNA virus metagenomics and demonstrated the presence of turkey-origin members of the Picornavirales, and the genus Caliciviridae, and the turkey picobirnaviruses. In order to better understand the viruses shed by pigeons, Phan et al. (2013) characterized enteric virome in droppings from wild pigeons and identified sequences of novel aviparvovirus, picornaviruses and described group $\mathrm{G}$ rotavirus from pigeons.

\section{Transcriptomics and virus-host interaction}

Initially, microarrays have been used to quantify gene expression. Introduction of NGS technologies revolutionized transcriptome profiling, an approach referred to as RNA sequencing (RNA-seq). NGS offers an opportunity 
for detailed examination of transcriptomics at both host and pathogen level during an infection, thereby, elucidating the mechanisms of disease and pinpointing the functional pathways involved in the host response to infection. Comprehensive analysis of AIV-infected lung tissue suggested that several microRNA (miRNAs) and mRNAs were likely to be involved in regulating the host response (Wang et al., 2012). Allele-specific expression (SNPs, genes and pathways) that was associated with transcriptional response to Marek's disease virus (MDV) infection was identified to underlay genetic basis for disease resistance to MDV infection in both broilers and layers (Perumbakkam et al., 2013). Gene expression patterns of normal and duck hepatitis A virus genotype $\mathrm{C}$ (DHAV-C) infected duck livers were explored and compared, and new insights into the molecular mechanism of host-DHAV-C interaction were provided (Tang et al., 2013). Huang et al. (2013) performed deep transcriptome analysis responsive to AIV using the lung of control ducks and ducks infected with highly pathogenic and weakly pathogenic $\mathrm{H} 5 \mathrm{~N} 1$ virus. The analysis revealed that $\beta$-defensin and butyrophilin-like gene repertoires were involved in host immune response. The information gained by using RNA-seq to obtain an overview of pathogen-induced host responses or to follow temporal expression changes during the infectious cycle can be exploited to design better control strategies as well as help in identification of genetic markers for disease resistance.

Chromatin immunoprecipitation (ChIP) was first developed to discover DNA-protein binding sites. ChIP coupled with high-throughput sequencing (ChIP-Seq) has been applied to quantitatively analyze binding sites of DNA associated proteins across the entire genome. ChIP-Seq has been reported to identify the binding sites in host genomes or transcription factors involved in virus infection and pathogenicity. Using chromatin immunoprecipitation-sequencing analysis, Subramaniam et al. (2013) identified binding sites occupied by MDV oncoprotein, (Meq) and/or c-Jun within the chicken genome and found enriched Meq binding sites in the promoter regions of upregulated genes. These technologies will contribute in achieving a comprehensive understanding of the DNA-binding profiles and epigenetic modification patterns associated with immune responses to both pathogens and vaccines.

\section{Evidence of causal virus-disease relationship}

NGS has provided a powerful tool for novel virus discovery but, it is only the first step to determine the etiology of a disease. To assign etiological agent, attempts should be made to accomplish Koch's postulates, which require the agent to be isolated in culture, or River's modifications, which recognize the added presence of neutralizing antibodies to an agent in evidence of infection or relationship between the presence of viral sequences and disease (Lipkin, 2013). Moreover, in vitro culture assays may be performed to assess the host range, cell tropism and entry receptors. Recent successes in identifying avian viruses and associating them with disease include DTMUV associated with severe egg drop syndrome (Huang et al., 2013). In case of unculturable viruses, the ability to construct infectious clones of novel virus, directly from clinical samples using either NGS denovo sequencing or by standard methods such as primer walking can be helpful in identifying etiological agents and characterization of the virus. For example, due to the lack of an efficient cell culture system for aHEV, Kwon et al. (2011) developed an infectious cDNA clone of aHEV strain recovered and assessed causality, pathogenicity and seroconversion in SPF chickens. To prove etiological agent using metagenomics, the metagenomic Koch's postulates have previously been introduced. They focus on the identification of metagenomic traits in diseased subjects (Mokili et al., 2012). However, this adaptation still requires the introduction of disease to prove causal virus-disease relationship (Bibby, 2013). Complicating disease association studies are the extent of viral genetic diversity and co-infections with other agents may influence clinical outcome. Deciphering such complex interactions will require viral metagenomics that query all virus families or genotypes in such cases, therefore, number of samples and repeatability in independent studies should be considered (Delwart, 2012).

\section{Conclusions and perspectives}

NGS platforms have been recognized as important tools in veterinary medicine which have enabled the discovery of viruses, viral diversity and development of viral metagenomics. Although adoption of NGS in routine clinical laboratory has enormous challenges due to the high costs of instruments and supplies, and requirements of skills and expert personnel to analyse the large datasets and their interpretation. As the cost and complexity of sequencing platforms are declining the routine use of NGS technology in the microbiology laboratory particularly in diagnostic clinical microbiology will become a routine practice. The discovery of novel viruses has been reported from wild and domestic birds. The discovery of these viruses will enable the development of diagnostic assays for the future detection or epidemiological investigation of viruses. Based on viral metagenomics approaches, complex gut viral community related to enteric syndrome in poultry and avian related gyroviruses were identified on human skin or in diarrheal samples. However, the identification of the etiological agents which are not proven yet, requires isolation of agent to fulfil Koch's postulates. 


\section{References}

Abolnik AC, Wandrag BR, Avian Dis. 58, 90-94, 2014. http://dx.doi. org/10.1637/10657-090313-Reg.1

Alkovskhovskii SV, Shchetinin, AM, Lvov DK, Shchelkanov MIu, Deriabin PG, Lvov DN, Samokhvalov EI, Gitelman AK, Botikov AG, Vopr. Virusol. 58, 10-13, 2013.

Allison AB, Keel MK, Philips JE, Cartoceti AN, Munk BA, Nemeth NM, Welsh TI, Thomas JM, Crum JM, Lichtenwalner AB, Fadly AM, Zavala G, Holmes EC, Brown JD, Virology 201, 450-451, 2014.

Allison AB, Palacios G, da Travassos RA, Popov VL, Lu L, Xiao SY, De Toy K, Briese T, Lipkin WI, Keel MK, Stallknecht DE, Bishop GR, Tesh RB, Virus Res. 155, 112-122, 2011. http://dx.doi.org/10.1016/j.virusres.2010.09.007

Banyai K, Toth AG, Ivanics E, Glavits R, Szentpali-Gavaller K, Dan A, Emerg. Infect. Dis. 18, 1365-1368, 2012. http://dx.doi. org/10.3201/eid1808.111669

Becker N, Jost H, Ziegler U, Eiden M, Hoper D, Emmerich P, Fichet-Calvet E, Ehichioya DU, Czajka C, Gabriel M, PLoS ONE 27, e32604, 2012. http://dx.doi.org/10.1371/ journal.pone. 0032604

Beerenwinkel N, Gunthard HF, Roth V, Metzner KJ, Challenges and opportunities in estimating viral genetic diversity from next-generation sequencing data. Front. Microbiol. 3, 329, 2012. http://dx.doi.org/10.3389/fmicb.2012.00329

Belak S, Karlsson OE, Blomstrom AL, Berg M, Granberg F, Vet. Microbiol. 165, 95-101, 2013. http://dx.doi.org/10.1016/j. vetmic.2013.01.022

Bennett MD, Gillett A, Vet. Microbiol. 168, 302-311, 2013. http:// dx.doi.org/10.1016/j.vetmic.2013.11.026

Beserra LA, Barbosa BR, Bernardes NT, Brandao PE, Gregori F, Avian Dis. 58, 153-157, 2014. http://dx.doi. org/10.1637/10626-080513-ResNote.1

Bexfield N, Kellam P, Vet. J. 190, 191-198, 2011. http://dx.doi. org/10.1016/j.tvjl.2010.10.014

Bibby K, Trends Biotech. 5, 275-279, 2013. http://dx.doi. org/10.1016/j.tibtech.2013.01.016

Bodewes R, van de Bildt MW, Schapendonk CM, van Leeuwen $\mathrm{M}$, van Boheemen S, de Jong AA, Osterhaus AD, Smits SL, Kuiken T, Virology 440, 84-88, 2013. http://dx.doi. org/10.1016/j.virol.2013.02.011

Boros A, Pankovics P, Knowles NJ, Nemes C, Delwart E, Reuter G, J. Virol. 88, 6434-6443, 2014. http://dx.doi.org/10.1128/ JVI.03807-13

Briand FX, Henry A, Massin P, Jestin V, J. Virol. 86, 7710, 2012. http://dx.doi.org/10.1128/JVI.00946-12

Bullman S, Kearney KO, Mahony M, Kelly L, Whyte P, Fanning S, Morgan JG, J. Gen. Virol. 95, 1094-1103, 2014. http:// dx.doi.org/10.1099/vir.0.061085-0

Chen GQ, Zhuang QY, Wang KC, Liu S, Shao JZ, Jiang WM, Hou GY, Li JP, Yu JM, Li YP, Chen JM, PLoS ONE 8, e72918, 2013. http://dx.doi.org/10.1371/journal. pone.0072918

Chu DK, Leung CY, Perera HK, Ng EM, Gilbert M, Joyner PH, Grioni A, Ades G, Guan Y, Peiris JS, Poon LL, J. Virol. 86, 13772-13778, 2012. http://dx.doi.org/10.1128/ JVI.02105-12
Croville G, Soubies SM, Barbieri J, Klopp C, Mariette J, Bouchez O, Camus-Bouclainville C, Guerin JL, J. Clin. Microbiol. 50, 2881-2887, 2012. http://dx.doi.org/10.1128/ JCM.01142-12

Dandar E, Balint A, Kecskemeti S, Szentpali-Gavaller K, Kisfali P, Melegh B, Farkas SL, Banyai K, Arch. Virol. 158, 2583-2588, 2013. http://dx.doi.org/10.1007/s00705-013 $-1739-y$

Dandar E, Huhtamo E, Farkas SL, Oldal M, Jakab F, Vapalahti O, Banyai K, J. Gen. Virol. 9, 898-904, 2014. http://dx.doi. org/10.1099/vir.0.060699-0

Day JM, Ballard LL, Duke MV, Scheffler BE, Zsak L, Virol. J. 7, 313, 2010. http://dx.doi.org/10.1186/1743-422X-7-313

Day JM, Zsak L, Avian Dis. 58, 137-142, 2014. http://dx.doi. org/10.1637/10593-061313-ResNote.1

de Vries M, Deijs M, Canuti M, van Schaik BDC, Faria NR, PLoS ONE 6, e16118, 2011. http://dx.doi.org/10.1371/journal. pone. 0016118

Delwart E, Curr. Opin. Virol. 2, 344-352, 2012. http://dx.doi. org/10.1016/j.coviro.2012.02.012

Dos Santos HF, Knak MB, de Castro FL, Slongo J, Ritterbusch GA, Klein TA, Esteves PA, Silva AD, Trevisol IM, Claassen EA, Vet. Microbiol. 155, 230-236, 2012. http://dx.doi. org/10.1016/j.vetmic.2011.09.021

Eckerle LD, Becker MM, Halpin RA, Li K, Venter E, Lu X, Scherbakova S, Graham RL, Baric RS, Stockwell TB, Spiro DJ, Denison MR, PLoS Pathogen 6, e1000896, 2010. http:// dx.doi.org/10.1371/journal.ppat.1000896

Farkas T, Fey B, Hargitt E 3rd, Parcells M, Ladman B, Murgia M, Saif Y, Virus Genes 44, 262-272, 2012. http://dx.doi. org/10.1007/s11262-011-0695-4

Fernandez-Pinero J, Davidson I, Elizalde M, Perk S, Khinich Y, Jimenez-Clavero MA, J. Gen. Virol. 95, 883-887, 2014. http://dx.doi.org/10.1099/vir.0.061465-0

Forrester NL, Widen SG, Wood TG, Travassos da Rosa AP, Ksiazek TG, Vasilakis N, Tesh RB, Virus Genes 47, 168-172, 2013. http://dx.doi.org/10.1007/s11262-013-0900-8

Garcia M, Volkening J, Riblet S, Spatz S, Virology 440, 64-74, 2013. http://dx.doi.org/10.1016/j.virol.2013.02.007

Grinev A, Chancey C, Anez G, Ball C, Winkelman V, Williamson P, Foster GA, Stramer SL, Rios M, Int. J. Environ. Res. Public. Health. 10, 4486-4506, 2013. http://dx.doi.org/10.3390/ ijerph10094486

Guy JS, Melissa AW, Frederick JF, Avian Dis. 55, 2-7, 2011. http:// dx.doi.org/10.1637/9504-081610-Reg.1

Gyuranecz M, Foster JT, Dan A, Ip, HS, Egstad KF, Parker PG, Higashiguchi JM, Skinner MA, Hofle U, Kreizinger Z, J. Virol. 87, 4938-4951, 2013. http://dx.doi.org/10.1128/ JVI.03183-12

Hall RJ, Wang J, Todd AK, Bissielo AB, Yen S, Strydom H, Moore NE, Ren X, Huang QS, Carter PE, Peacey M, J. Virol. Methods 195, 194-204, 2014. http://dx.doi.org/10.1016/j. jviromet.2013.08.035

Hicks JA, Liu HC, Avian Dis. 57, 332-339, 2013. http://dx.doi. org/10.1637/10355-090812-Review.1

Honkavuori KS, Briese T, Krauss S, Sanchez MD, Jain K, Hutchison SK, Webster RG, Lipkin WI, PLoS ONE 9, e93395, 2014. http://dx.doi.org/10.1371/journal.pone.0093395 
Honkavuori KS, Shivaprasad HL, Briese T, Street C, Hirschberg DL, Hutchison SK, Lipkin WI, Emerg. Infect. Dis. 17, 480-487, 2011. http://dx.doi.org/10.3201/eid1703.101410

Honkavuori KS, Shivaprasad HL, Williams BL, Quan PL, Hornig M, Street C, Palacios G, Hutchison SK, Franca M, Egholm M, Briese T, Lipkin WI, Emerg. Infect. Dis 14, 1883-1886, 2008. http://dx.doi.org/10.3201/eid1412.080984

Hoper D, Kalthoff D, Hoffmann B, Beer M, J. Virol. 86, 1394-1404, 2012. http://dx.doi.org/10.1128/JVI.00797-11

Hsu IW, Tsai HJ, Emerg. Infect. Dis. 20, 149-151, 2014. http://dx.doi. org/10.3201/eid2001.131224

Huang X, Han K, Zhao D, Liu Y, Zhang J, Niu H, Zhang K, Zhu J. Wu D, Gao L, Li Y, Res. Vet. Sci. 94, 774-780, 2013. http:// dx.doi.org/10.1016/j.rvsc.2012.11.014

Huang Y, Li Y, Burt DW, Chen H, Zhang Y, Qian W, Kim H, Gan S, Zhao Y, Li J, Nat. Genet. 45, 776-783, 2013. http://dx.doi. org/10.1038/ng.2657

Iqbal M, Reddy KB, Brookes SM, Essen SC, Brown IH, McCauley JW, PLoS ONE 9, e87076, 2014. http://dx.doi.org/10.1371/ journal.pone. 0087076

Jackwood MW, Hall D, Handel A, Infect. Genet. Evol. 12, 1305-1311, 2012. http://dx.doi.org/10.1016/j.meegid.2012.05.003

Jackwood MW, Boynton TO, Hilt DA, McKinley ET, Kissinger JC, Paterson AH, Robertson J, Lemke C, McCall AW, Williams SM, Virology 398, 98-108, 2010. http://dx.doi. org/10.1016/j.virol.2009.11.044

Johne R, Muller H, Rector A, van Ranst M, Stevens H, Trends Microbiol. 17, 205-211, 2009. http://dx.doi.org/10.1016/j. tim.2009.02.004

Jones BA, Grace D, Kock R, Alonso S, Rushton J, Said MY, McKeever D, Mutua F, Young J, McDermott J, Pfeiffer DU, Proc. Natl. Acad. Sci. USA 110, 8399-8404, 2013. http:// dx.doi.org/10.1073/pnas.1208059110

Jonges M, Welkers MR, Jeeninga RE, Meijer A, Schneeberger P, Fouchier RA, de Jong MD, Koopmans M, J. Virol. 88, 1694-1702, 2014. http://dx.doi.org/10.1128/JVI.02044$\underline{13}$

Kajan GL, Stefancsik R, Ursu K, Palya V, Benko M, Virus Res. 153, 226-233, 2010. http://dx.doi.org/10.1016/j. virusres.2010.08.006

Kessell A, Hyatt A, Lehmann D, Shan S, Crameri S, Holmes C, Marsh G, Williams C, Tachedjian M, Yu M, Emerg. Infect. Dis. 18, 2044-2046, 2012. http://dx.doi.org/10.3201/ eid1812.120500

Kistler AL, Gancz A, Clubb S, Skewes-Cox P, Fischer K, Sorber K, Chiu CY, Lublin A, Mechani S, Farnoushi Y, Greninger A, Wen CC, Karlene SB, Ganem D, DeRisi JL, Virol. J. 5, 88, 2008. http://dx.doi.org/10.1186/1743-422X-5-88

Kofstad T, Jonassen CM, PLoS ONE 6, e25964, 2011. http://dx.doi. org/10.1371/journal.pone.0025964

Ku CS, Roukos DH, Expert Rev. Med. Devices 10, 1-6, 2013. http:// dx.doi.org/10.1586/erd.12.63

Kwon HM, LeRoith T, Pudupakam RS, Pierson FW, Huang YW, Dryman BA, Meng XJ, Vet. Microbiol. 147, 310-319, 2011. http://dx.doi.org/10.1016/j.vetmic.2010.07.016

Ledermann JP, Zeidner N, Borland EM, Mutebi JP, Lanciotti RS, Miller BR, Lutwama JJ, Tendo JM, Andama V, Powers
AM, J. Gen. Virol. 95, 1436-1443, 2014. http://dx.doi. org/10.1099/vir.0.060764-0

Lee SW, Devlin JM, Markham JF, Noormohammadi AH, Browning GF, Ficorilli NP, Hartley CA, Markham PF, PLoS ONE 8, e55121, 2013. http://dx.doi.org/10.1371/journal. pone.0055121

Lee YJ, Kang HM, Lee EK, Song BM, Jeong J, Kwon YK, Kim HR, Lee KJ, Hong MS, Jang I, Choi KS, Kim JY, Lee HJ, Kang MS, Jeong OM, Baek JH, Joo YS, Park YH, Lee HS. Emerg. Infect. Dis. 20, 1087-1089, 2014.

Li Y, Liu X, Yang Z, Xu C, Liu D, Qin J, Dai M, Hao J, Feng M, Huang X, J. Virol. 88, 3182-3191, 2014. http://dx.doi. org/10.1128/JVI.02995-13

Liais E, Croville G, Mariette J, Delverdier M, Lucas MN, Klopp C, Lluch J, Donnadieu C, Guy, JS Corrand L, Emerg. Infect. Dis. 20, 105-108, 2014. http://dx.doi.org/10.3201/ eid2001.130774

Lipkin WI, Firth C, Curr. Opin. Virol. 3, 199-204, 2013. http:// dx.doi.org/10.1016/j.coviro.2013.03.010

Llorente F, Pérez-Ramírez E, Fernández-Pinero J, Soriguer R, Figuerola J, Jiménez-Clavero MA, Emerg. Infect. Dis. 19, 1023-1025, 2013. http://dx.doi.org/10.3201/ eid1906.130122

Mackenzie JS, Jeggo M, Curr. Opin. Virol. 3, 170-179, 2013. http:// dx.doi.org/10.1016/j.coviro.2013.02.002

Mardis ER, Annu. Rev. Anal. Chem. 6, 287-303, 2013. http://dx.doi. org/10.1146/annurev-anchem-062012-092628

Marek A, Ballmann MZ, Kosiol C, Harrach B, Schlotterer C, Hess M, J. Gen. Virol. 95, 156-170, 2014. http://dx.doi. org/10.1099/vir.0.057711-0

Marek A, Kosiol C, Harrach B, Kajan GL, Schlotterer C Hess M, Vet. Microbiol. 166, 250-256, 2013. http://dx.doi. org/10.1016/j.vetmic.2013.05.017

Maughan MN, Bliss TW, Chung I, Suarez DL, Keeler CL Jr, J. Microb. Biochem. Technol. S2, 005, 2014.

Miller PJ, Afonso CL, Spackman E, Scott MA, Pedersen JC, Senne DA, Brown JD, Fuller CM, Uhart MM, Karesh WB, J. Virol. 84, 11496-11504, 2010. http://dx.doi.org/10.1128/ JVI.00822-10

Mokili JL, Rohwer F, Dutilh BE, Curr. Opin. Virol. 2, 63-77, 2012. http://dx.doi.org/10.1016/j.coviro.2011.12.004

Monne I, Fusaro A, Nelson, MI, Bonfanti L, Mulatti P, Hughes J, Murcia PR, Schivo A, Valastro V, Moreno A, J. Virol. 88, 4375-4388, 2014. http://dx.doi.org/10.1128/JVI.03181$\underline{13}$

Ng TF, Cheung AK, Wong W, Lager KM, Kondov NO, Cha Y, Murphy DA, Pogranichniy RM, Delwart E, 1, e0013413, 2013.

Nguyen TT, Kwon HJ, Kim IH, Hong SM, Seong WJ, Jang JW, Kim JH, J. Virol. Methods 188, 41-46, 2013. http://dx.doi. org/10.1016/j.jviromet.2012.12.004

Palacios G, Forrester NL, Savji N, Travassos da Rosa AP, Guzman H, Detoy K, Popov VL, Walker PJ, Lipkin WI, Vasilakis N, Tesh RB, Virol. J. 10, 219, 2013. http://dx.doi. org/10.1186/1743-422X-10-219

Pankovics P, Boros A, Reuter G, Arch. Virol. 157, 525-530, 2012. http://dx.doi.org/10.1007/s00705-011-1192-8 
Park YM, Kim JH, Gu SH, Lee SY, Lee MG, Kang YK, Kang SH, Kim, HJ, Song JW, Virology 422, 144-150, 2012. http:// dx.doi.org/10.1016/j.virol.2011.10.008

Parvin R, Heenemann K, Halami MY, Chowdhury EH, Islam MR, Vahlenkamp TW, Arch. Virol. 159, 1651-1661, 2014. http://dx.doi.org/10.1007/s00705-014-1976-8

Pello SJ, Olsen GH, Vet. Clin. North Am. Exot. Anim. Pract. 16, 357381, 2013. http://dx.doi.org/10.1016/j.cvex.2013.02.001

Perumbakkam S, Muir WM, Black-Pyrkosz A, Okimoto R, Cheng HH, BMC Genomics. 14, 64, 2013. http://dx.doi. org/10.1186/1471-2164-14-64

Phan TG, Vo NP, Boros Á, Pankovics P, Reuter G, Li OT, Wang C, Deng X, Poon LL, Delwart E, PLoS ONE. 8, e72787, 2013. http://dx.doi.org/10.1371/journal.pone.0072787

Pinette MM, Rodriguez-Lecompte JC, Pasick J, Ojkic D, Leith M, Suderman M, Berhane Y, J. Immunol. Methods 405, 167 177, 2014. http://dx.doi.org/10.1016/j.jim.2014.02.004

Radford AD, Chapman D, Dixon L, Chantrey J, Darby AC, Hall N, J. Gen. Virol. 93, 1853-1868, 2012. http://dx.doi. org/10.1099/vir.0.043182-0

Ramakrishnan MA, Tu ZJ, Singh S, Chockalingam AK, Gramer MR, Wang P, Goyal SM, Yang M, Halvorson DA, Sreevatsan S, PLoS ONE. 4, e7105, 2009. http://dx.doi.org/10.1371/ journal.pone.0007105

Ramey AM, Reeves AB, Ogawa H, Ip HS, Imai K, Bui VN, Yamaguchi E, Silko NY, Afonso CL, Arch. Virol.158, 2495-2503, 2013. http://dx.doi.org/10.1007/s00705-013 -1761-0

Reuter G, Boros A, Delwart E, Pankovics P, Arch. Virol. 159, 2161-2164, 2014. http://dx.doi.org/10.1007/s00705-014 $\underline{-2025-3}$

Ribeiro Silva R, Bezerra DA, Kaiano JH, Oliveira D de S, Silvestre RV, Gabbay YB, Ganesh B, Mascarenhas JD, J. Gen. Virol. 95, 117-122, 2014. http://dx.doi.org/10.1099/ vir.0.054783-0

Rijsewijk FA, Dos Santos HF, Teixeira TF, Cibulski SP, Varela AP, Dezen D, Franco AC, Roehe PM, Arch. Virol. 156, 1097-1100, 2011. http://dx.doi.org/10.1007/s00705-011 -0971-6

Rosseel T, Van Borm S, Vandenbussche F, Hoffmann B, van den Berg T, PLoS ONE 8, e76144, 2013. http://dx.doi.org/10.1371/ journal.pone.0076144

Rosseel T, Lambrecht B, Vandenbussche F, van den Berg T, Van Borm S, Virol. J. 6, 463, 2011 http://dx.doi.org/10.1186/1743$\underline{422 X-8-463}$

Rubbenstroth D, Schmidt V, Rinder M, Legler M, Corman VM, Staeheli, Vet. Microbiol. 168, 318-323, 2014. http://dx.doi. org/10.1016/j.vetmic.2013.11.032

Sarker S, Patterson EI, Peters A, Baker GB, Forwood JK, Ghorashi SA, Holdsworth M, Baker R, Murray N, Raidal SR, PLoS ONE 9, e85370, 2014. http://dx.doi.org/10.1371/journal. pone. 0085370

Schade B, Schmitt F, Böhm B, Alex M, Fux R, Cattoli G, Terregino C, Monne I, Currie RJ, Olias P, Avian Dis. 57, 159-163, 2013. http://dx.doi.org/10.1637/10330-082312-Case.1

Schumann T, Hotzel H, Otto P, Johne R, Virology 386, 334-343, 2009. http://dx.doi.org/10.1016/j.virol.2009.01.040
Seimon TA, McAloose D, Raphael B, Honkavuori KS, Chang T, Hirschberg DL, Lipkin WI, Vet. Pathol. 49, 482-491, 2012. http://dx.doi.org/10.1177/0300985811424733

Shivaprasad HL, Phalen DN, Avian Pathol. 41, 531-539, 2012. http:// dx.doi.org/10.1080/03079457.2012.732692

Snoeck CJ, Adeyanju AT, Owoade AA, Couacy-Hymann E, Alkali BR, Ottosson U, Muller CP, Appl. Environ. Microbiol. 79, 7867-7874, 2013. http://dx.doi.org/10.1128/AEM.02716$\underline{13}$

Spatz SJ, Volkening JD, Keeler CL, Kutish GF, Riblet SM, Boettger CM, Clark KF, Zsak L, Afonso CL, Mundt ES, Rock DL, Garcia M, Virus Genes 44, 273-285, 2012. http://dx.doi. org/10.1007/s11262-011-0696-3

Steinmetz HW, Bakonyi T, Weissenböck H, Hatt JM, Eulenberger U, Robert N, Hoop R, Nowotny N, Vet. Microbiol. 148, 207-212, 2011. http://dx.doi.org/10.1016/j. vetmic.2010.09.018

Subramaniam S, Johnston J, Preeyanon L, Brown CT, Kung HJ, Cheng HH, J. Virol. 87, 9016-9029, 2013. http://dx.doi. org/10.1128/JVI.01163-13

Sujayanont P, Chininmanu K, Tassaneetrithep B, Tangthawornchaikul N, Malasit P, Suriyaphol P, J. Virol. Methods 195, 141-147, 2014. http://dx.doi.org/10.1016/j. jviromet.2013.10.005

Tang C, Lan D, Zhang H, Ma J, Yue H, PLoS ONE 8, e71051, 2013. http://dx.doi.org/10.1371/journal.pone.0071051

Terregino C, Aldous EW, Heidari A, Fuller CM, De Nardi R, Manvell RJ, Beato MS, Shell WM, Monne I, Brown IH, Alexander DJ, Capua I, Arch. Virol. 158, 2233-2243, 2013. http:// dx.doi.org/10.1007/s00705-013-1735-2

To KK, Tsang AK, Chan JF, Cheng VC, Chen H, Yuen KY, J. Infect. 68, 205-215, 2014. http://dx.doi.org/10.1016/j. jinf.2013.12.014

Travassos da Rosa AP, Mather TN, Takeda T, Whitehouse CA, Shope RE, Popov VL, Guzman H, Coffey L, Araujo TP, Tesh RB, Emerg. Infect. Dis. 8, 614-618, 2002. http:// dx.doi.org/10.3201/eid0806.010384

Trojnar E, Sachsenröder J, Twardziok S, Reetz J, Otto PH, Johne R, J. Gen. Virol. 94, 136-142, 2013. http://dx.doi.org/10.1099/ vir.0.047381-0

Van Borm S, Rosseel T, Steensels M, van den Berg T, Lambrecht B, Virus Res. 171, 186-193, 2013. http://dx.doi.org/10.1016/j. virusres.2012.11.017

Victoria JG, Wang C, Jones MS, Jaing C, McLoughlin K, Gardner S, Delwart EL, J. Virol. 84, 6033-6040, 2010. http://dx.doi. org/10.1128/JVI.02690-09

Wang C, Wang J, Su W, Gao S, Luo J, Zhang M, Xie L, Liu S, Liu X, Chen Y, Jia Y, Zhang, H, Ding H, He H, J. Infect. Dis. 209, 34-37, 2014a. http://dx.doi.org/10.1093/infdis/jit478

Wang X, Liu N, Wang F, Ning K, Li Y, Zhang D, J. Gen. Virol. 95, 1289-1296, 2014b. http://dx.doi.org/10.1099/ vir.0.063313-0

Wang G, Deng G, Shi J, Luo W, Zhang G, Zhang Q, Liu L, Jiang Y, Li C, Sriwilaijaroen, N, J. Virol. 88, 3953-3964, 2014c. http://dx.doi.org/10.1128/JVI.03292-13

Wang Y, Lupiani B, Reddy SM, Lamont SJ, Zhou H, Poult. Sci. 93, 485-493, 2014d. http://dx.doi.org/10.3382/ps.2013$\underline{03557}$ 
Wang Y, Brahmakshatriya V, Lupiani B, Reddy SM, Soibam B, Benham AL, Gunaratne P, Liu HC, Trakooljul N, Ing N, Okimoto R, Zhou H, BMC Genomics 13, 278, 2012. http://dx.doi.org/10.1186/1471-2164-13-278

Wojnarowicz C, Olkowski A, Schwean-Lardner K, Can. Vet. J. 48, 1270-1271, 2007.

Wolf S, Reetz J, Hoffmann K, Grundel A, Schwarz BA, Hanel I, Otto, PH, Arch. Virol. 157, 1499-1507, 2012. http://dx.doi. org/10.1007/s00705-012-1326-7

Woo PC, Lau SK, Huang Y, Lam CS, Poon RW, Tsoi HW, Lee P, Tse H, Chan AS, J. Gen. Virol. 91, 2433-2448, 2010. http:// dx.doi.org/10.1099/vir.0.021717-0

Woo PC, Lau SK, Lam CS, Lai KK, Huang Y, Lee P, Luk GS, Dyrting KC, Chan KH, Yuen KY, J. Virol. 83, 908-917, 2009. http://dx.doi.org/10.1128/JVI.01977-08
Wu A, Su C, Wang D, Peng Y, Liu M, Hua S, Li T, Gao GF, Tang H, Chen J. Cell Host Microbe 14, 446-452, 2013. http:// dx.doi.org/10.1016/j.chom.2013.09.001

Yao Y, Smith LP, Nair V, Watson M, J. Virol. 88, 2-9, 2014. http:// dx.doi.org/10.1128/JVI.02921-13

Yao Y, Smith LP, Petherbridge L, Watson M, Nair V, J. Gen. Virol. 93, 1530-1536, 2012. http://dx.doi.org/10.1099/ vir.0.040634-0

Yu K, Sheng ZZ, Huang B, Ma X, Li Y, Yuan X, Qin Z, Wang D, Chakravarty S, Li F, Song, M, Sun, H, PLoS ONE 8, e 71319, 2013.

Yu, X, Jin T, Cui Y, Pu X, Li J, Xu J, Liu G, Jia H, Liu D, Song S J. Virol. 88, 3423-3431, 2014. http://dx.doi.org/10.1128/ JVI.02059-13 